\title{
Remediation of Simulated Landfill's Leachate Using Waterworks Sludge and Other Conventional Materials
}

\author{
Israa M. Ali ${ }^{1, *}$, and Ayad A. H. Faisal ${ }^{2}$ \\ ${ }^{1}$ Department of Environmental engineering, Baghdad University, Baghdad, Iraq, is87raa@yahoo.com \\ ${ }^{2}$ Department of Environmental engineering, Baghdad University, Baghdad, Iraq, ayadabedalhamzafaisal@yahoo.com \\ * Corresponding Author: Israa M. Ali, email: is87raa@yahoo.com \\ Published online: 31 August 2019
}

Abstract- The possibility of utilizing waterworks sludge as byproduct from water supply treatment plant for the remediation of simulated leachate contaminated with cadmium, dissolved organic matter (COD), and ammonia nitrogen $\left(\mathrm{NH}_{3}-\mathrm{N}\right)$ was investigated through batch study in comparison with conventional sorbents specifically activated carbon and ion-exchange resin Amberlite IR120 Na. Batch sorption experiments of single and multi-components systems were conducted to represent the acetogenic phase $(\mathrm{pH}=5.5)$. Results proved that the sludge, activated carbon and ion-exchange resin are efficient sorbents for removal of cadmium, $\mathrm{COD}$, and $\mathrm{NH}_{3}-\mathrm{N}$ respectively with removal efficiencies ranged from 35 to $95 \%$ for all experiments. Equilibrium isotherms were analyzed using the Langmuir and Freundlich models. Kinetic data were obtained and analyzed using pseudo-first-order and pseudo second-order equations. The sorption isotherm data were fitted well to the Langmuir isotherm and the monolayer adsorption capacity was found as $5.634,14.908$ and $3.938 \mathrm{mg} / \mathrm{g}$ for sorption of $\mathrm{Cd}$ (II) onto sludge, $\mathrm{NH}_{3}-\mathrm{N}$ onto resin and COD onto activated carbon respectively.

Keywords - leachate; Waterworks sludge; Kinetic models; Isotherm models; Conventional materials.

\section{Introduction}

Sanitary landfilling considers the most prevalent technique to dispose municipal solid waste (MSW) in comparison with other disposal techniques. This is due to its several advantages such as simple disposal procedure, economically cheap disposal method, and landscaperestoring effect [33]. However, the huge quantity of a high polluted landfill leachate can be produced and formed a potential negative impact of this disposal method [29;30]. Leachate has relatively high concentrations of COD, ammonia nitrogen and heavy metals. Combination of organic and inorganic pollutants existing in landfill leachate needs sorbents that have the ability to remove the various types of pollutants. In this direction, water treatment sludge was tested in comparison with commercial activated carbon (CAC) and ion-exchange resin as reactive material. Many studies are investigated the possibility of using the dewatered waterworks sludge for heavy metals removal from landfill leachate [25]. This sludge is low-cost and easily available worldwide; and it is generated during the drinking-water treatment process. It is primarily composed of $\mathrm{Fe} / \mathrm{Al}$ hydroxides which are often amorphous species; and it contains sediment and humic substances from the raw water. The results of many studies certified that the dewatered waterworks sludge have large surface areas and high affinity for heavy metals such as cadmium, chromium, copper, zinc, lead and others [32; 38]. When alum salts were added to raw turbid water sources during drinking water purification process, aluminum ions were hydrolyzed into aluminum hydroxide which is a precipitate $[5 ; 7]$. Water insoluble impurities and other organic matter in the raw water can be absorbed by aluminum hydroxide precipitates after the flocculationclarification process during treatment process. Alum sludge is primarily formulated as gelatinous amorphous structures and consistors of organic and suspended matter, inorganic matter, various microbial consortia, coagulant products and chemical substances $[5 ; 36]$. Activated carbon is the most effective adsorbent that have high capacities for removing a wide range of organic and inorganic contaminants due to its surface, which typically have high density of phenolic and carboxylic groups [20]. In addition, previous studies have confirmed that different types of ion-exchange resins were an excellent sorbent to remove NH3-N from the aqueous solution, due to its high 
removal efficiency and relatively simple operation $[4 ; 10]$. Ion-exchange process involves a reversible interchange of ions between liquid and solid phase; i.e., the mobile ions of ion-exchange material can be replaced by similar charged ions from the surrounding medium [4]. There is limited studies concern with using waterworks sludge to remove $\mathrm{COD}, \mathrm{NH} 3-\mathrm{N}$ and $\mathrm{Cd}(\mathrm{II})$ present together in the aqueous solution. Accordingly, the aim of this study is to investigate the ability of waterworks sludge to remediate the simulated landfill's leachate in comparison with CAC and ion-exchange resin.

\section{Materials and Methods}

\subsection{Sorbents}

Waterworks sludge was collected from AL-Weihdaa water treatment plant (WTP)/ Baghdad/ Iraq (Fig.1). This plant use alum salts in the purification of the raw water. The sludge was air-dried for three days and, then, it was grinded and passed through the mesh size ranged from 1 $\mathrm{mm}$ to $63 \mu \mathrm{m}$ with geometric mean diameter $\left(\mathrm{d}_{\mathrm{gm}}\right)$ of 0.25 mm which was calculated by $d_{g m}=\left(d_{1} d_{2}\right)^{1 / 2}$ where $d_{1}$ and $d_{2}$ are the diameters of the lower and upper sieves respectively [23]. The sludge was also characterized using $\mathrm{X}$-ray diffraction analysis test to determine its mineralogy.
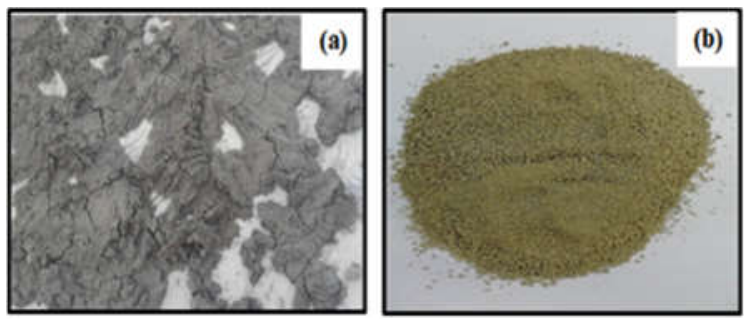

Figure 1: Waterworks sludge (a) natural (b) after drying and sieving.

Commercial activated carbon (CAC) was purchased from local market crushed and sieved in order to obtain the particle size distribution approximately the same as that of sludge described previously. Also, synthetic ion-exchange resin product Amberlite IR120 Na was chosen as reactive material in the present study. This material is an industrial grade strong acid cation exchanger (obtained from DOW Chemical Co.). The resin was washed with distilled water to remove dirt and any chemical impurities and, then, it was dried at $105 \mathrm{oC}$ for $12 \mathrm{hr}$. It was pretreated with strong acid $0.1 \mathrm{~N} \mathrm{HCl}$ to completely convert cation exchanger to their $\mathrm{H}+$ form [10]. After that, resin was washed with distilled water to remove all the acid and dried at room temperature.

\subsection{Contaminants}

Three types of stock solutions were prepared to achieve the requirements of this study as follows:

1) Stock solution of cadmium with concentration of $1000 \mathrm{mg} / \mathrm{L}$ was prepared by dissolving certain quantity
(2.744 g) of $\mathrm{Cd}\left(\mathrm{NO}_{3}\right)_{2} .4 \mathrm{H}_{2} \mathrm{O}$ in $1 \mathrm{~L}$ of distilled water and used as a stock solution.

2) Synthetic ammonia stock solution of $1000 \mathrm{mg} / \mathrm{L}$ was prepared by dissolving $3.819 \mathrm{~g}$ of $\mathrm{NH}_{4} \mathrm{Cl}$ in $1 \mathrm{~L}$ of distilled water after drying it for $3 \mathrm{hrs}$ at $105^{\circ} \mathrm{C}$.

3) Dissolved organic matter (COD) with concentration of $9000 \mathrm{mg} / \mathrm{L}$ was prepared by dissolving $11.535 \mathrm{~g}$ of sodium acetate anhydrous in the $1 \mathrm{~L}$ of distilled water. All stocks solutions were diluted to get the desirable concentration, and the $\mathrm{pH}$ of all solutions was changed to get acidic conditions $5.5 \pm 0.1$ to represent the acetogenic phase of leachate in all experiments by adding $0.1 \mathrm{M} \mathrm{HCl}$ or $\mathrm{NaOH}$ as required.

Finally, the synthetic leachate is prepared using the same procedure adopted in reference [8] and the constituents of this leachate are summarized in Table 1. The concentrations of $\mathrm{COD}, \mathrm{NH}_{3}-\mathrm{N}$ and $\mathrm{Cd}(\mathrm{II})$ in this leachate have values of $6520-8700,510-544$ and $32 \pm 2$ $\mathrm{mg} / \mathrm{L}$ respectively.

Table 1: Synthetic landfill leachate composition constituents per liter.

\begin{tabular}{|c|c|}
\hline Constituent & Value \\
\hline Acetic acid (99\%) & $7 \mathrm{~mL}$ \\
\hline $\mathrm{K} 2 \mathrm{HPO} 4$ & $30 \mathrm{mg}$ \\
\hline $\mathrm{KHCO} 3$ & $312 \mathrm{mg}$ \\
\hline $\mathrm{K} 2 \mathrm{CO} 3$ & $324 \mathrm{mg}$ \\
\hline $\mathrm{NaNO} 3$ & $50 \mathrm{mg}$ \\
\hline $\mathrm{NaHCO} 3$ & $3012 \mathrm{mg}$ \\
\hline $\mathrm{CaCl} 2 \cdot 2 \mathrm{H} 2 \mathrm{O}$ & $2882 \mathrm{mg}$ \\
\hline $\mathrm{MgCl} 2 \cdot 6 \mathrm{H} 2 \mathrm{O}$ & $3114 \mathrm{mg}$ \\
\hline $\mathrm{MgSO} 4$ & $156 \mathrm{mg}$ \\
\hline $\mathrm{NH} 4 \mathrm{HCO} 3$ & $2439 \mathrm{mg}$ \\
\hline $\mathrm{CO}(\mathrm{NH} 2) 2$ & $695 \mathrm{mg}$ \\
\hline $3 \mathrm{CdSO} 4 \cdot 8 \mathrm{H} 2 \mathrm{O}$ & $80 \mathrm{mg}$ \\
\hline
\end{tabular}

\subsection{Experimental Work}

All batch experiments were conducted based on the acetogenic phase that characterized by acidic conditions. So that the $\mathrm{pH}$ of the solutions was adjusted to get $5.5( \pm$ 0.1 ) at room temperature. The batch experiments were conducted to investigate the ability of chosen reactive materials namely; sludge collected from water supply treatment plant, $\mathrm{CAC}$ and ion-exchange resin to remediate the solution contaminated with COD, NH3-N and/or Cd(II) .

A series of $250 \mathrm{~mL}$ conical-flasks were employed and each flask was filled with $100 \mathrm{~mL}$ of $\mathrm{Cd}(\mathrm{II})$ solution which have an initial concentration of $50 \mathrm{mg} / \mathrm{L}$. Different doses of sludge $(0.5,1,5,10$, and 20$) \mathrm{g}$ were added to the solutions in the flasks. The solution in each flask was kept stirred on an agitation speed at $200 \mathrm{rpm}$ for 2 hours using orbital shaker (Edmund Buhler SM25, German). A fixed volume $(20 \mathrm{~mL})$ of the contaminated solution was withdrawn from each flask, and filtered using filter paper type (JIAO JIE 
102) to separate the sorbent. A fixed volume $(10 \mathrm{~mL})$ of the filtrated solution was pipetted out for analysis to measure the concentration of the remaining contaminant. The measurements were carried out using atomic absorption spectrophotometer (AAS, Sens AA, Australian). The best value of sludge dosage was found 5 $\mathrm{g}$ and this value was used in the remaining experiments. The experiments for specifying the best contact time were carried out by withdrawn samples periodically throw the time periods ranged from 10 to $120 \mathrm{~min}$. Additional tests were conducted to study the effect of initial concentration and agitation speed on the removal efficiency of cadmium where concentrations are changed in the range from 50 to $250 \mathrm{mg} / \mathrm{L}$, while agitation speeds have values of $0,50,100$, 150,200 , and $250 \mathrm{rpm}$.

The experiments described previously were repeated to investigate the ability of sludge to remove NH3-N (600 $\mathrm{mg} / \mathrm{L})$ and COD $(8660 \mathrm{mg} / \mathrm{L})$ from aqueous solution using high values of sludge dosages $(\geq 50 \mathrm{~g} / 100 \mathrm{~mL})$. The remaining concentrations of $\mathrm{NH} 3-\mathrm{N}$ in the solution were measured using KJELTEC AUC 1030 analyzer by distillation and titration method, while the COD concentrations were measured by the photometer (Lovibond Multidirect Sn 11/3942, Germany). Results proved that the sludge is suitable for remediation of aqueous solutions contaminated with cadmium and low removal efficiency was achieved for NH3-N while it was not suitable to remove COD. These results are certified that other reactive materials must be adopted to achieve the acceptable removal for NH3-N and COD. In this direction, $\mathrm{CAC}$ and Amberlite ion-exchange resin were adopted and tested in the set of experiments similar to that mentioned previously.

Accordingly, a set of experiments were achieved using $\mathrm{CAC}$ and ion-exchange resin where dosage of sorbent was ranged from 0.5 to $70 \mathrm{~g}$ per $100 \mathrm{~mL}$ for different values of initial concentrations. Results proved that the CAC is suitable for treating the water contaminated with COD while the NH3-N can be removed efficiently by Amberlite IR120 $\mathrm{Na}$ resin adopted in the present study. Additional experiments were conducted for investigating the ability of sludge, resin and $\mathrm{CAC}$ to treat leachate (i.e. solution contaminated with COD, NH3-N and $\mathrm{Cd}(\mathrm{II})$ ) because this is the common situation in the sanitary landfill. The conditions of these experiments are specified depended on the best conditions for single interaction between the contaminants and sorbents under consideration described in the previous paragraphs. The results for leachate interaction with sorbents were consistent with results of single interaction where sludge, resin and CAC can be suitable for $\mathrm{Cd}(\mathrm{II}), \mathrm{NH} 3-\mathrm{N}$ and COD respectively. The removal efficiency for all contaminants was calculated as follows:

$$
R=\frac{\left(C_{o}-C_{e}\right)}{C_{o}} \times 100
$$

Where $\mathrm{Co}$ and $\mathrm{Ce}$ are indicating to the initial and equilibrium concentrations of contaminant $(\mathrm{mg} / \mathrm{L})$. The amount of sorbate retained in the sorbent material phase, qe $(\mathrm{mg} / \mathrm{g})$, can be determined by:

$$
q_{e}=\left(C_{o}-C_{e}\right) \frac{V}{m}
$$

Where $m$ is the sorbent quantity that added to the flask (g) and $\mathrm{V}$ is the volume of aqueous solution (L). The sorption data were fitted with Langmuir, and Freundlich models. Also, kinetic data were represented using Pseudo-first order, and Pseudo-second order models.

\section{Sorption Isotherm}

The importance of this models is finding the specific relationship correlated between the sorbed amount of sorbate onto solid surface (qe) and the concentration of sorbate remaining at equilibrium $(\mathrm{Ce})$ in the aqueous solution [37]. Two sorption isotherm models are used to describe the obtained results as follows:

1) Langmuir model: it is used for uniform energies of sorption onto the surface of sorbent and can be represented as [12]:

$$
q_{e}=\frac{q_{\max } b C_{e}}{1+b C_{e}}
$$

where $q_{\max }$ is the maximum sorption capacity $(\mathrm{mg} / \mathrm{g})$ and $b$ is the sorbate affinity to the sorbent which represents the slope of the model.

\section{2) Freundlich model:}

$$
q_{e}=a_{F} C_{e}^{b_{F}}
$$

where $a_{F}$ is a constant related to the maximum adsorption capacity of the adsorbent and $b_{F}$ (usually less than 1) is the intensity of sorption [13]. This empirical isotherm model is applicable for multilayer sorption and heterogeneous surfaces [17].

\section{Sorption kinetics}

The rate at which the dissolved pollutant is transferred from aqueous solution to solid phase is very important in the design of appropriate sorption treatment processes [28]. The kinetic data measured in the present study was represented using the following models:

1) Pseudo-first order kinetic model: it is written as follows [34]:

$$
\frac{d q}{d t}=k_{1}\left(q_{e}-q_{t}\right)
$$

Integrating linearize Eq. (5) with the conditions; $" t=0$ to $t$ $=\mathrm{t}$ and $\mathrm{q}_{\mathrm{t}}=0$ to $\mathrm{q}_{\mathrm{t}}=\mathrm{q}_{\mathrm{t}}$ ", gives:

$$
\ln \left(q_{e}-q_{t}\right)=\ln q_{e}-k_{1} t
$$

Non-linear form of Eq. (6) can be rewritten to represent the pseudo first order reaction as the following form: 


$$
q_{t}=q_{e}\left(1-e^{-k_{1} t}\right)
$$

where $q_{t}$ and $q_{e}$ are the quantities of sorbate removed from the aqueous solution of pollutants at time $t$ and at equilibrium respectively in $(\mathrm{mg} / \mathrm{g})$, and $k_{l}$ is the pseudo first order rate constant $(1 / \mathrm{min})$.

2) Pseudo-second order kinetic model: the assumption of this model that is monolayer of sorbate is attached to the sorbent surface, energy of sorption is the same for each sorbent and there is no interaction between sorbed species. The model can be described as [16]:

$$
q_{t}=\frac{t}{\left(\frac{1}{k_{2} q_{e}^{2}}+\frac{t}{q_{e}}\right)}
$$

where $k_{2}$ is the pseudo second order rate constant $(\mathrm{g} / \mathrm{mg}$ $\min )$.

\section{Results and Discussion}

\subsection{Waterworks sludge}

Fig.2 shows the variation of removal efficiencies of Cd(II) as a function of sludge dosage. It is clear that the removal efficiency of $\mathrm{Cd}$ (II) increased from 37.5 to $97.5 \%$ when dosage changed from $0.5 \mathrm{~g}$ to $20 \mathrm{~g}$ respectively. This was logicale due to the fact that the higher dose of sorbents in the solution, the greater availability of vacant sites [1]. The results proved that $5 \mathrm{~g}$ of used sludge was sufficient to achieve the acceptable value of removal efficiency $(=93.6 \%)$ and no more significant increase in the removal efficiency can be recognized due to doubling of sludge quantity, therefore, this value will be used as best dosage in the next experiments.

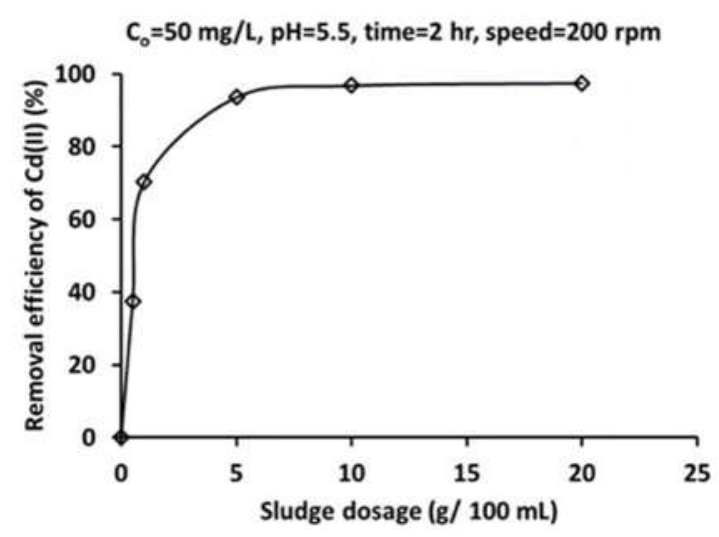

Figure 2: Effect of waterworks sludge dose on the removal efficiency of Cd (II) from aqueous solution.

Fig.3 signified that the removal efficiency was increased rapidly in the initial stages and, then, become gradually constant after $30 \mathrm{~min}$ where the removal efficiency was $92 \%$ until reached to $94 \%$ after 2 hrs. This behavior can be attributed to the enough sorbent sites that presence for sorption of contaminant in the initial stages [11]. In addition, Fig. 4 revealed that little decline occurred in the removal efficiency of cadmium ions onto the waterworks sludge when the $\mathrm{Cd}(\mathrm{II})$ initial concentration had increased from 50 to $100 \mathrm{mg} / \mathrm{L}$ with a corresponding removal efficiency of almost $86 \%$. This figure also revealed the decline in the removal efficiencies of cadmium ions will continue until to reach the value of $65 \%$ at concentration of $250 \mathrm{mg} / \mathrm{L}$. The reason for the decline of the removal efficiency can be explained as the higher the concentration is, the higher the driving force for the mass transfer from the bulk solution to the surface of the sorbent materials and this will obviously make no more sorption sites available particularly during the first stages of the process.

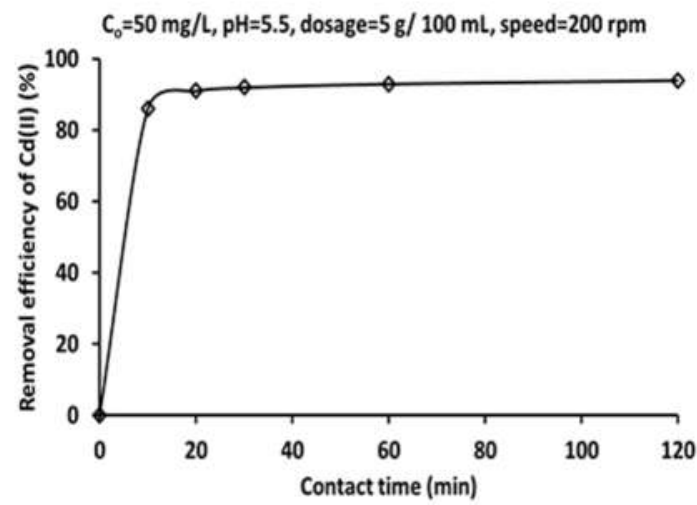

Figure 3: Effect of contact time on the removal efficiency of $\mathrm{Cd}$ (II) from aqueous solution using waterworks sludge.

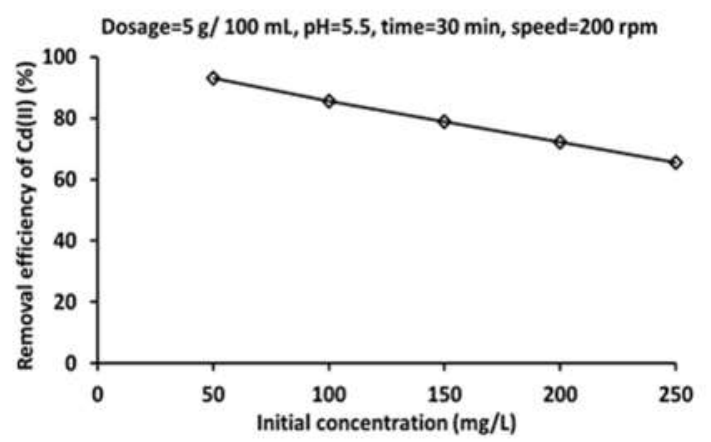

Figure 4: Effect of initial concentration on the removal efficiency of Cd (II) from aqueous solution using waterworks sludge.

Also, there is a concomitant increase in the removal efficiency of cadmium from zero speed (no agitation) corresponding to an efficiency of $49 \%$ to $250 \mathrm{rpm}$ corresponding to $95 \%$ removal as shown in Fig.5. The reason for increasing the removal efficiency of the contaminant with increasing the numbers of rpm impaired to the mass-liquid medium can be explained as the higher the speed of agitation; the higher the migration of metal ions toward the active sites on the sorbents. 


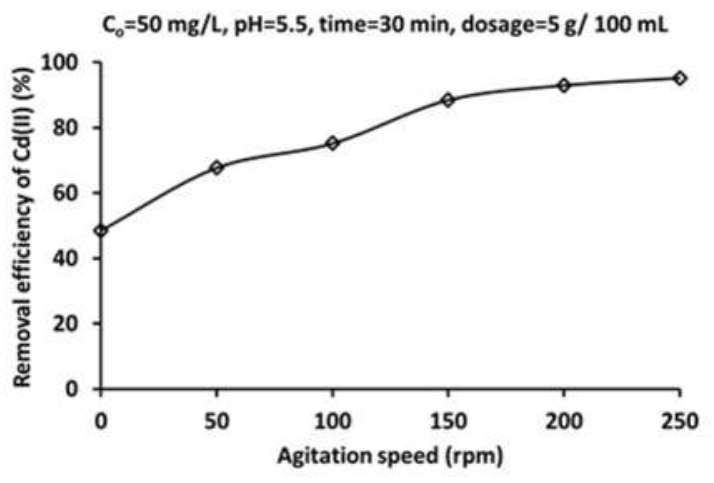

Figure 5: Effect of agitation speed on the removal efficiency of $\mathrm{Cd}$ (II) from aqueous solution using waterworks sludge.

Finally, the interaction of waterworks sludge with $\mathrm{NH}_{3}-\mathrm{N}$ and COD was studied. Fig.6 illustrates that this sorbent has low ability in the removal of $\mathrm{NH}_{3}-\mathrm{N}$ and the maximum removal efficiency was not exceeding of $29 \%$ when sorbent dosage equal to $90 \mathrm{~g} / 100 \mathrm{~mL}$. The low efficiency may be due to the low affinity of $\mathrm{NH}_{3}-\mathrm{N}$ toward the used sludge. The results, also, proved that the COD with initial concentration of $8660 \mathrm{mg} / \mathrm{L}$ was increased due to increase the sorbent dosage until arrive to the value of $9760 \mathrm{mg} / \mathrm{L}$ at sludge dosage of $80 \mathrm{~g}$ (Fig.7). This can be attributed to the presence of organic matter in the composition of used sludge and this result in agreement with many previous studies such as [14]. Indeed, when alum is added to raw water it flocculates as hydroxyl-Al species and organic matter as well as other insoluble impurities can be absorbed by aluminum hydroxide precipitates after the flocculation-clarification process during treatment process $[9 ; 21]$. The study presented by Ippolito [19] signified that the organic matter in sludge resulted from water supply treatment plant ranged from 63 to $144(\mathrm{~g} / \mathrm{Kg})$ and, accordingly, this is explained the results of the present study.

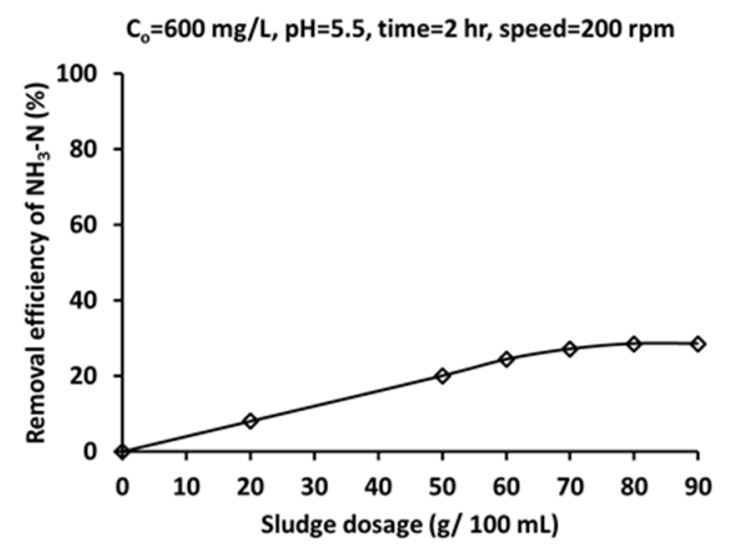

Figure 6: Removal efficiency of NH3-N from aqueous solution using waterworks sludge as a function of sorbent dosage.

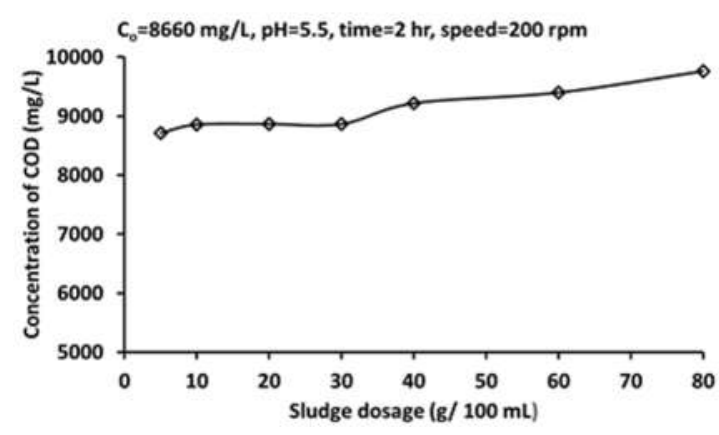

Figure 7: The variation of dissolved organic matter (COD) in the aqueous solution after the interaction with waterworks sludge.

\subsection{Commercial activated carbon}

Fig.8 illustrate that the removal efficiency of COD was increased from 13 to $69.5 \%$ due to change of CAC doses from 5 to $70 \mathrm{~g}$ for initial concentration of $500 \mathrm{mg} / \mathrm{L}$. The increasing of removal efficiency may be due to the hydrophobic surfaces themselves; microspore structure, high adsorption capacity, and active surfaces that make CAC more suitable in the adsorption of organic materials [15]. The increasing in the CAC dosage did not cause any significant change in the removal efficiency due to reaching the sorption capacity. This figure certifies that increasing of initial concentration from 500 to $3000 \mathrm{mg} / \mathrm{L}$ lead to increase of contaminant uptake from 0.676 to 2.615 $\mathrm{mg} / \mathrm{g}$, however, this uptake at the low initial concentration of contaminant is increased rapidly and it begins slightly increasing with increase of concentration. In addition, the removal efficiency of COD decreased due to increase of the initial concentration. On the other hand, the removal efficiency of NH3-N is not exceeded $27 \%$ when sorbent dosage equal to $50 \mathrm{~g}$ (Fig. 9) and this value is considered very low in comparison with removal efficiency of COD using the same dosage of sorbent. This result can be attributed probably to non-polarity surfaces of CAC which may be caused a poor interaction between the polar substances [27]. Also, the sorption capacity in milligram of NH3-N per gram of CAC was decreased from 0.514 to 0.243 with increasing of sorbent dosage from 5 to $70 \mathrm{~g} /$ $100 \mathrm{~mL}$ until stabilized at certain value because there is inversely relationship between them. Accordingly, the CAC can be adopted for treating the water contaminated with dissolved organic matter (COD). So, the next task is finding the sorbent that has ability to remediate the water contaminated with $\mathrm{NH} 3-\mathrm{N}$ and this can be investigated through the section concerned the ion-exchange resin. 


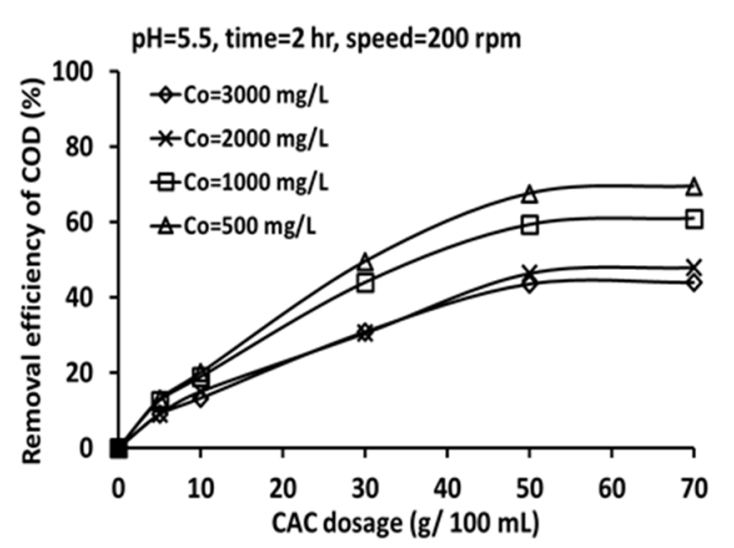

Figure 8: Variation of COD removal efficiency as a function of CAC dosage for different values of initial organic matter concentration.

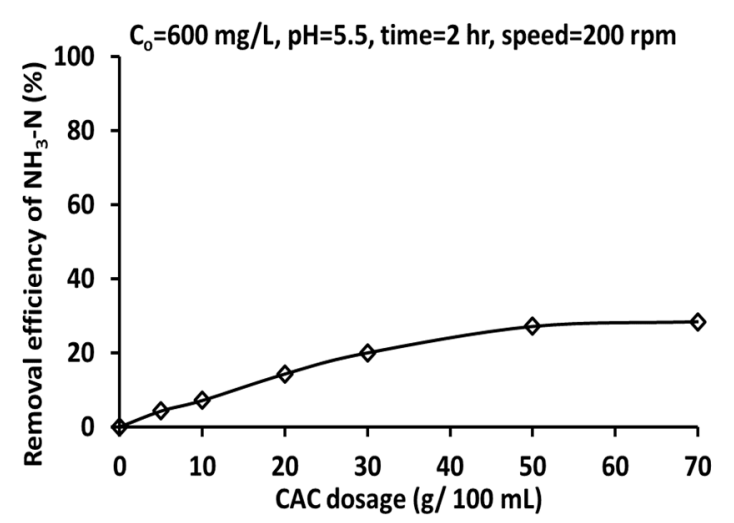

Figure 9: Variation of NH3-N removal efficiency as a function of CAC dosage.

Fig.10 shows that the removal efficiency of COD significantly increased with increasing in contact time. The sorption rate was rapid at the initial stages and gradually slowed down afterwards. The slower sorption was likely due to the decrease in sorption sites on the surface of CAC media, therefore, the sorption curve has been stabilized after almost $60 \mathrm{~min}$.

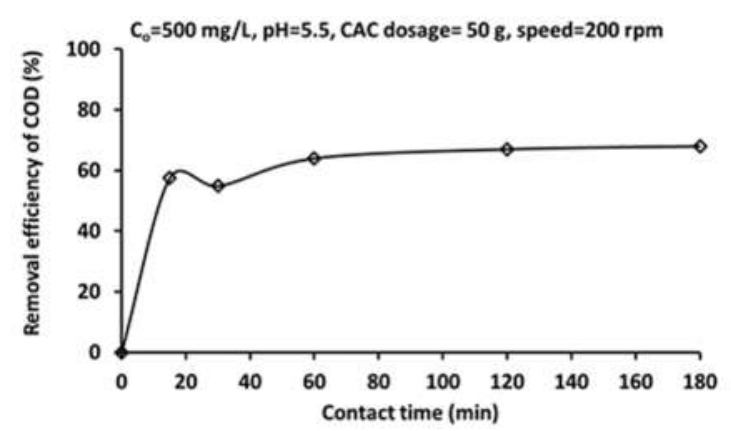

Figure 10: Effect of contact time on the removal efficiency of COD from aqueous solution using CAC sorbent.

\subsection{Amberlite Ion-exchange resin}

The relationship between the removal efficiency of NH3$\mathrm{N}$ with change of sorbent dosage from 0.5 to $20 \mathrm{~g}$ is plotted in Fig. 11 where the corresponding efficiency varied from 8 to $86 \%$ for initial concentration of NH3-N equal to 600 $\mathrm{mg} / \mathrm{L}$. These results can be explained on the basis that the ion exchange resins are insoluble materials and they are contained exchangeable mobile ions. Once the resin comes in contact with the aqueous solution, the ion separates and becomes mobile. The ions on the exchanger can be replaced via dissolved ions in the aqueous phase to keep the overall charge neutral. Consequently, removal of positive ions, such as NH3-N, principally occurs due to the strong exchangeability with the cationic resin mobile ion $(\mathrm{H}+)$ [35]. Fig.12 shows the removal efficiency of ammonia using Amberlite ion-exchange resin as a function of time using $20 \mathrm{~g}$ sorbent dose added to $100 \mathrm{~mL}$ of contaminated solution. It is clear that the removal percentage is increased with increasing of contact time in the first $5 \mathrm{~min}$ and, then, equilibrium was reached. After that, there was no significant increase in removal value and this result was in good agreement with previous studies such as [10].

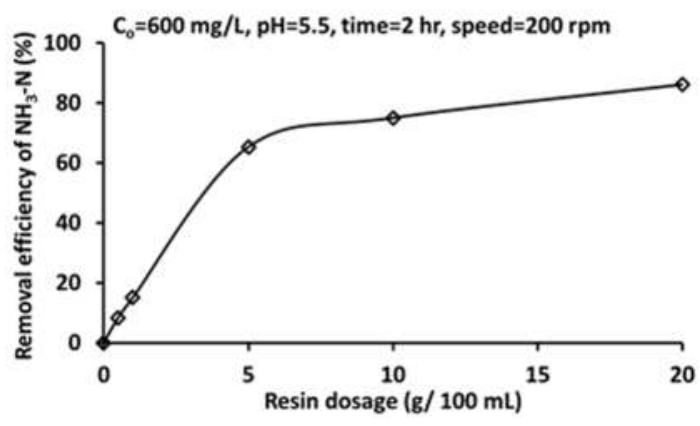

Figure 11: Effect of resin dosage on NH3-N removal by Amberlite ion-exchange resin.

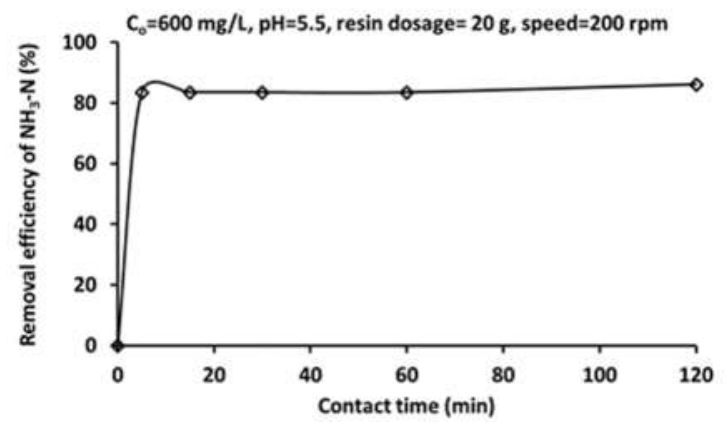

Figure 12: Effect of contact time on NH3-N removal by Amberlite ion-exchange resin.

\subsection{Synthetic leachate}

The leachate prepared in the present study is simulated the one generated from sanitary landfill in the acetogenic phase with characteristics summarized in Table 1. The 
concentrations of the $\mathrm{Cd}(\mathrm{II}), \mathrm{COD}$ and NH3-N have values of $6520-8700,510-544$ and $32 \pm 2 \mathrm{mg} / \mathrm{L}$ respectively. These concentrations are considered greater than the allowable discharge limits as stipulated by the Malaysian Environmental Quality Act 1974 (Control of Pollution from Solid Waste Transfer Station and Landfill) Regulations 2009 [3]. These regulations are specified the values of discharge limits for COD and NH3-N as 400 and $5 \mathrm{mg} / \mathrm{L}$, however, the concentrations of heavy metals have low values. Therefore, the current experiments have focused on the removal efficiencies of Cd(II), COD, and NH3-N from simulated acetogenic leachate. Due to its characteristics, the prepared leachate is recognized as highly contaminated leachate with organic and inorganic pollutants, hence the application of physicochemical processes for effective treatment is required.

Removal of the combination of organic and inorganic pollutants that comprise the major constituents of landfill leachate requires sorbent with the ability to remove various types of these pollutants. It was proved in the previous sections that activated carbons are the most effective adsorbents for the removal of organic pollutants from aqueous phase. However, activated carbon generally does not have sufficient adsorption capacity for the removal of ammonia because it usually possesses a non-polar surface due to manufacturing conditions at high temperatures, which is considered a drawback in many applications and this lead to poor interaction with polar adsorbates .[27]

Accordingly, many studies have recently been conducted to develop methods for solving this situation and finding a procedure that able to achieve the final acceptable remediation for target contaminants. The most method adopted in the previous literatures was modified the surfaces of activated carbon or producing composite adsorbent with broad capabilities to interact with either polar or non-polar adsorbates. However, another method was adopted in this study which is required to investigate the treatability of acetogenic leachate resulted from landfill by passing it through a three-stage experiment at the same best operation conditions for single component systems and these stages can be summarized as follows:

- Stage 1: in this stage, waterworks sludge was utilized for leachate treatment with contact time of $30 \mathrm{~min}$ and sludge dosage of $5 \mathrm{~g} / 100 \mathrm{~mL}$ as well as the agitation speed of 200 rpm.

- Stage 2: after achievement the step 1, the remaining leachate was treated by utilizing Amberlite ion-exchange resin with contact time of $30 \mathrm{~min}$ and ion-exchange resin dosage of $14 \mathrm{~g} / 70 \mathrm{~mL}$.

- Stage 3: finally, the leachate passed the stages 1 and 2 was treated with CAC at contact time of $60 \mathrm{~min}$ and CAC dosage of $10 \mathrm{~g} / 20 \mathrm{~mL}$.

Fig.13 shows the achieved removal efficiencies of each contaminant (i.e. Cd(II), COD, and NH3-N) for each stage described previously. Each removal efficiency through certain stage was determined based on the initial and final concentrations of contaminant for that stage, however, the total removal efficiency for certain contaminant through the three stage was calculated depended on the influent and effluent concentrations regardless the role of any stage. It is clear that the total removal efficiency of $\mathrm{Cd}$ (II) was equal to $95 \%$ and this is very logically because each stage (i.e. sorbent) has definite ability to remove this contaminant. In addition, the achieved removal efficiencies of NH3-N and COD have values of $84 \%$ and $35 \%$ respectively, however, these values can be considered acceptable.

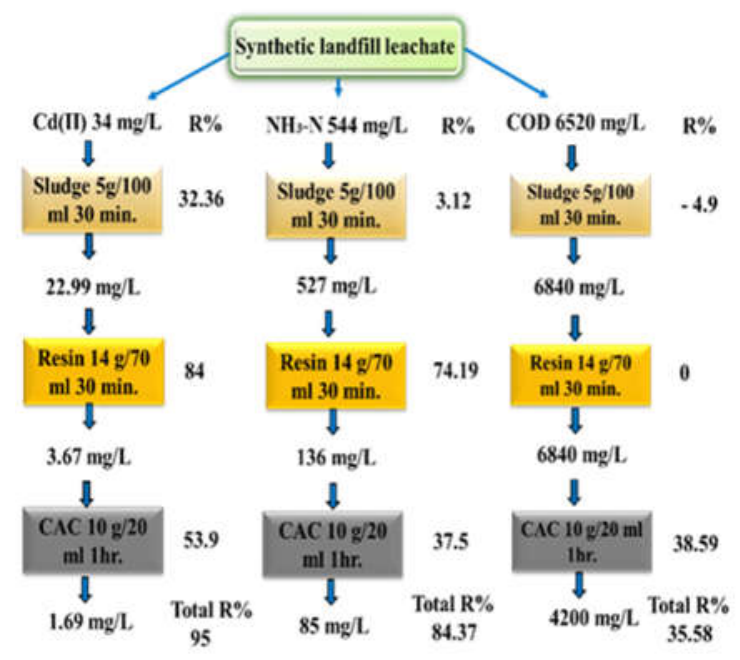

Figure 13: Treatment of synthetic leachate using three stages consisted of waterworks sludge, ion-exchange resin and $\mathrm{CAC}$ in series configuration.

Difference between the removal efficiencies of COD in the leachate and single component system can be attributed to high difference in the initial concentrations of COD and the presence of waterworks sludge in the first-stage will cause an increase in the COD concentration of the leachate. In addition, the difference between the results of leachate and single system for contaminants under consideration can be attributed primarily to the competition of the components of leachate. This means that the affinity of each compound present in the leachate with respect to certain sorbent will play a significant role in specifying the achieved removal efficiency for each contaminant.

\subsection{X-ray diffraction analysis}

The waterworks sludge was characterized using the X-ray diffraction analysis (BRUKER) conducted in Germany Laboratory/ Geology Department/ College of Science/ University of Baghdad. Fig.14 proved that the silica, calcite and feldspar are the main components with proportions of $78.2,17.3$ and $4.5 \%$ respectively. The results proved that the silicon dioxide $(\mathrm{SiO} 2)$, i.e. quartz, is the major constituent of silica and the sand in the waterworks sludge can be resulted from sedimentation processes of raw turbid water. The presence of quartz enhance the adsorption of the heavy metals through ligand complexation due to develop a negative charge on the 
sludge [31]. Also, the measured percentage of calcite in a good agreement with many previous studies such as [22; 18]. The presence of calcite, i.e $\mathrm{CaCO} 3$ in the sludge may have the role in the removal of NH3-N even with low value as mentioned by [2]. In spite of the aluminum is formed the principle constituent of the feldspar, but its percentage is very low and this may be due to add low quantities of .[38] alum to raw water through coagulation flocculation processes. However, this percentage of aluminum was able to remove of heavy metals and, finally ,the present results of XRD analysis in good agreement with previous study such as

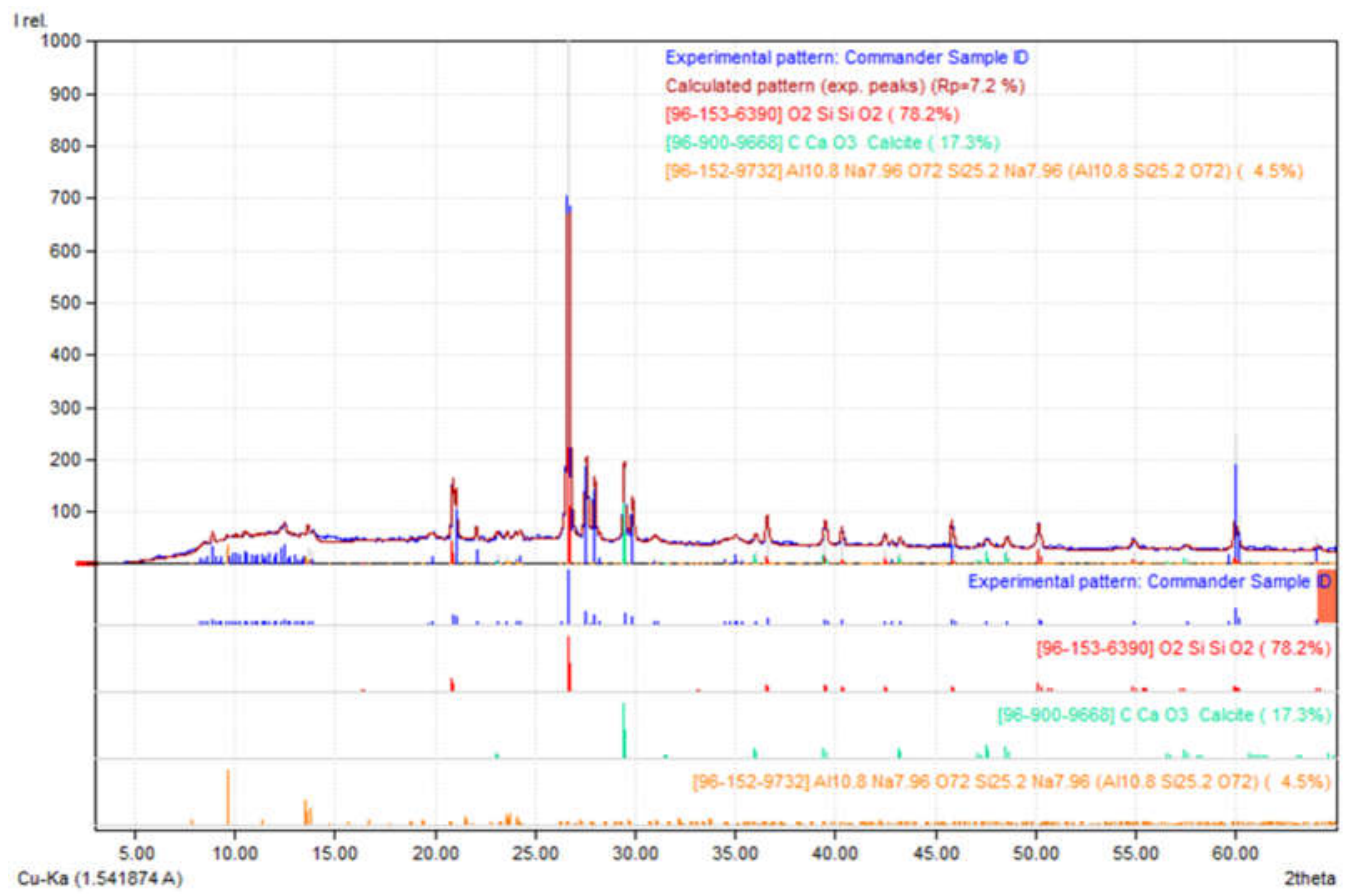

Figure 14: The X-ray diffraction (XRD) analysis for waterworks sludge used in the present study.

\subsection{Sorption isotherms}

The results described in the previous sections proved that the waterworks sludge, ion-exchange resin and CAC are suitable for remediation of aqueous solutions contaminated with $\mathrm{Cd}(\mathrm{II}), \mathrm{NH} 3-\mathrm{N}$ and COD respectively. So, the relationships between the sorbed quantity of each pollutant (qe, $\mathrm{mg} / \mathrm{g}$ ) and the equilibrium concentration (Ce) for representing the interactions of $\mathrm{Cd}(\mathrm{II})$ with sludge, NH3-N with resin and COD with CAC are modeled using Freundlich and Langmuir models. These models were fitted with measured sorption data and the constants of all models can be determined by using nonlinear regression method in the Microsoft Excel (2016) [6] where these goodness parameters and constants are listed in Table 2 . It is clear from Fig. 15 and Table 2 that the goodness between the experimental and predicted values was good for adopted models. The statistical measures (i.e. R2 and SSE) signified that the Langmuir model is more dependable tool to describe the amount of $\mathrm{Cd}(\mathrm{II})$ and $\mathrm{NH} 3-\mathrm{N}$ sorbed onto sludge and resin respectively, however, the two models are able to describe the sorption of COD onto CAC. The calculated maximum sorption capacities of the $\mathrm{Cd}$ (II) onto sludge, NH3-N onto resin and COD onto CAC are equal to $5.634,14.908$ and $3.938 \mathrm{mg} / \mathrm{g}$ respectively. The applicability of Langmuir model means that the surfaces of sorbents are homogeneous where all the sorption sites assumed to have an equal sorbate affinity and the sorption at one site does not effect on the sorption at an adjacent site [26]. In addition, it is clear that the values of Freundlich (or affinity) constants are greater than 1 and this certify occurrence of the favorable sorption [25].

Table 2: Constants of isotherm models used in the present study for sorption of $\mathrm{Cd}(\mathrm{II})$ onto sludge, $\mathrm{NH} 3-\mathrm{N}$ onto resin and $\mathrm{COD}$ onto CAC.

\begin{tabular}{|c|c|c|c|c|}
\hline Model & Parameter & Cd(II)/Sludge & $\begin{array}{c}\mathbf{N H}_{3}-\mathbf{N} / \\
\text { Resin }\end{array}$ & COD/CAC \\
\hline \multirow{5}{*}{ Langmuir } & $\begin{array}{c}q_{\max } \\
(\mathrm{mg} / \mathrm{g})\end{array}$ & 5.634 & 14.908 & 3.938 \\
\cline { 2 - 5 } & $b(\mathrm{~L} / \mathrm{mg})$ & 0.0786 & 0.0035 & 0.0010 \\
\cline { 2 - 5 } & $\mathrm{SSE}$ & 0.4307 & 3.7425 & 0.0692 \\
\cline { 2 - 5 } Freundlich & $\mathrm{R}^{2}$ & 0.9735 & 0.9524 & 0.9840 \\
\hline & $\begin{array}{c}a_{F}(\mathrm{mg} \\
/ \mathrm{mg})(\mathrm{L} \\
/ \mathrm{mg})^{b_{F}}\end{array}$ & 0.5490 & 0.3477 & 0.0366 \\
\cline { 2 - 5 } & $b_{F}$ & 0.5880 & 0.5316 & 0.5711 \\
\cline { 2 - 5 } & $\mathrm{SSE}^{2}$ & 1.0952 & 5.2705 & 0.0189 \\
\cline { 2 - 5 } & $\mathrm{R}^{2}$ & 0.9264 & 0.9323 & 0.9954 \\
\hline
\end{tabular}




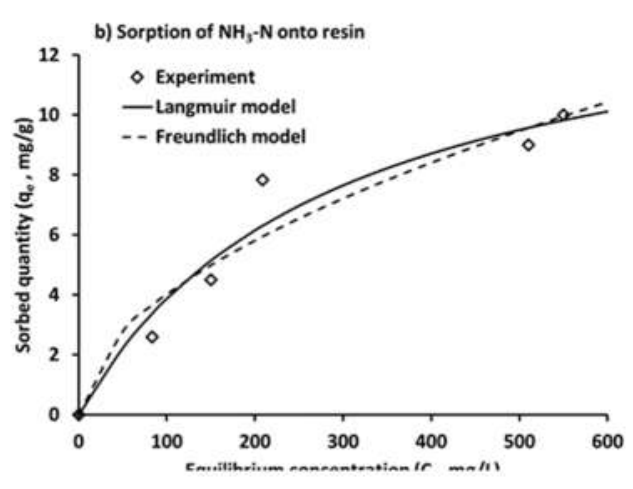

values. Also, Fig.16 (b) shows that the uptake of NH3-N by ion-exchange resin increased with an increasing of contact time in the first $20 \mathrm{~min}$ and, then, the equilibrium was reached where this result is consistent with results reported by [10].
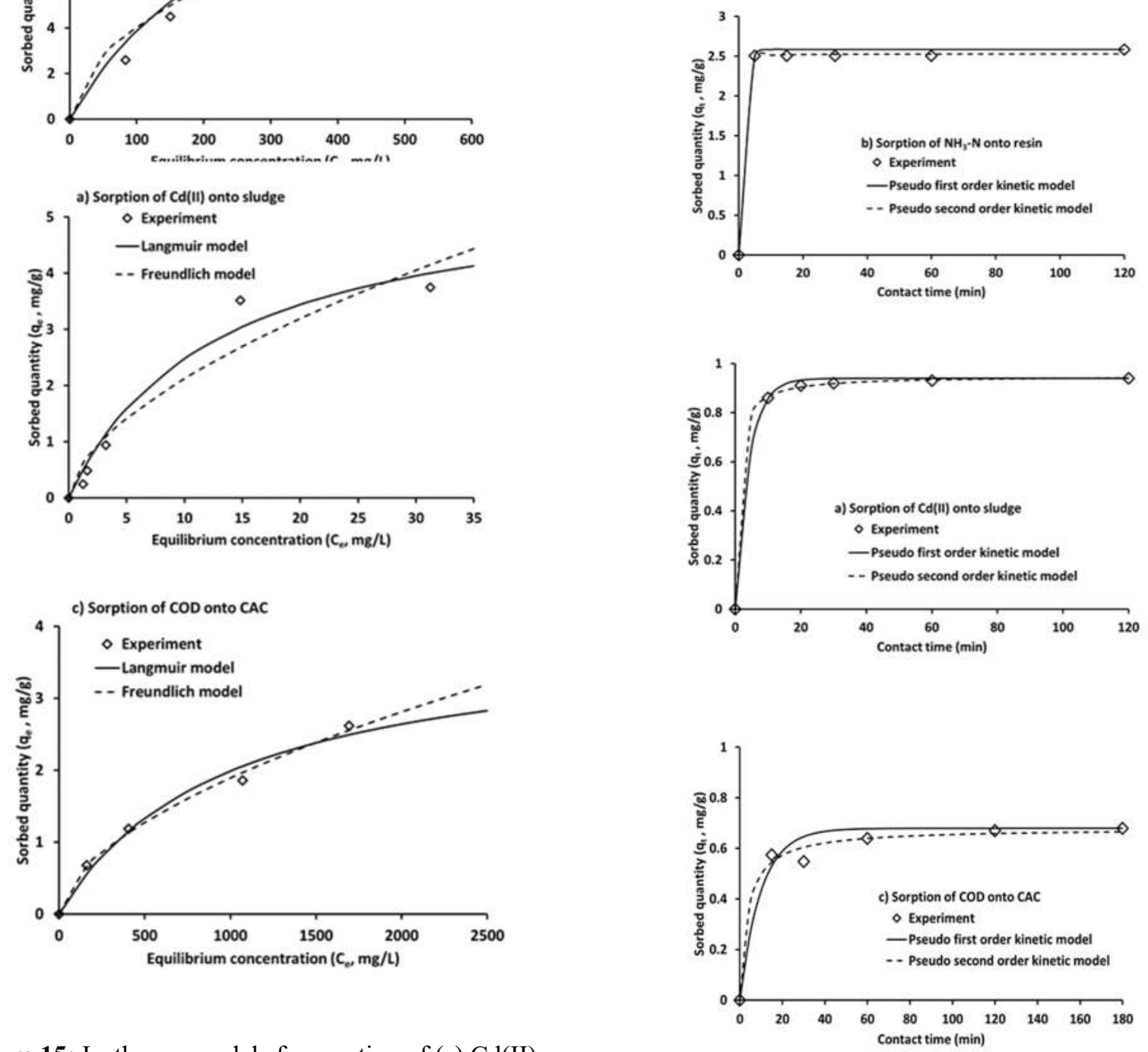

Figure 15: Isotherms models for sorption of (a) $\mathrm{Cd}(\mathrm{II})$ onto sludge, (b) NH3-N onto resin and (c) COD onto CAC.

\subsection{Sorption kinetics}

The pseudo first-order and pseudo second-order models were used to fit the experimental data in the same manner that used in the plotting of sorption isotherms by using non-liner regression method as shown in Fig.16 and the constants of these models are listed in Table 3. It is clear that the two models are able to explain the relationships between the experimental and predicted values, however, pseudo-second order model for sorption of $\mathrm{Cd}(\mathrm{II})$ onto sludge, NH3-N onto resin and COD onto CAC gave a better fit based on the values of SSE and R2. This indicating that the sorption process was controlled by chemisorption [16]. In addition, the calculated values of sorbed quantity for sorption of contaminants onto the sorbents are in a good agreement with the experimental

Figure 16: Isotherms models for sorption of (a) $\mathrm{Cd}(\mathrm{II})$ onto sludge, (b) NH3-N onto resin and (c) COD onto CAC.

Table 3: Constants of isotherm models used in the present study for sorption of $\mathrm{Cd}(\mathrm{II})$ onto sludge, NH3-N onto resin and COD onto CAC.

\begin{tabular}{|c|c|c|c|c|}
\hline $\begin{array}{c}\text { Kinetic } \\
\text { model }\end{array}$ & Parameter & Cd(II)/Sludge & $\begin{array}{c}\mathbf{N H}_{3-} \\
\mathbf{N} / \\
\text { Resin }\end{array}$ & COD/CAC \\
\hline $\begin{array}{c}\text { Pseudo- } \\
\text { first order }\end{array}$ & $q_{e}(\mathrm{mg} / \mathrm{g})$ & 0.94 & 2.5833 & 0.68 \\
\cline { 2 - 5 } & $k_{l}\left(\mathrm{~min}^{-1}\right)$ & 0.2409 & 0.6987 & 0.1006 \\
\hline
\end{tabular}




\begin{tabular}{|c|c|c|c|c|}
\hline & $\mathrm{SSE}$ & 0.00099 & 0.0184 & 0.0133 \\
\cline { 2 - 5 } & $\mathrm{R}^{2}$ & 0.9996 & 0.9986 & 0.9683 \\
\hline \multirow{4}{*}{$\begin{array}{c}\text { Pseudo- } \\
\text { second } \\
\text { order }\end{array}$} & $\begin{array}{c}k_{2}(\mathrm{~g} / \mathrm{mg} / \mathrm{g}) \\
\mathrm{min})\end{array}$ & 0.9489 & 2.5325 & 0.6793 \\
\cline { 2 - 5 } & $\mathrm{SSE}$ & 0.00006 & 0.0041 & 0.0044 \\
\cline { 2 - 5 } & $\mathrm{R}^{2}$ & 0.9999 & 0.9992 & 0.9869 \\
\hline
\end{tabular}

\section{Conclusions}

Batch study proved that the waterworks sludge can be used as effective sorbent for remediation of aqueous solutions contaminated with $\mathrm{Cd}(\mathrm{II})$. The best operating conditions that achieved $93 \%$ removal efficiency of $\mathrm{Cd}$ (II) for initial concentration $50 \mathrm{mg} / \mathrm{L}$ with $\mathrm{pH}=5.5 \pm 0.1$ (simulated acetogenic phase of leachate) were; dosage $5 \mathrm{~g} / 100 \mathrm{~mL}$, agitation time of $30 \mathrm{~min}$ and shaking speed of $200 \mathrm{rpm}$. While the same sorbent was not suitable for removing NH3-N and COD. On the other hand, CAC was effective in removing COD with efficiency of $69.5 \%$ using sorbent dosage $70 \mathrm{~g}$ per $100 \mathrm{~mL}$ for initial concentration of 500 $\mathrm{mg} / \mathrm{L}$. Finally, ion-exchange resin was the more suitable sorbent to remove NH3-N from aqueous solution in comparison with sludge and CAC. The best dosage of ion exchange resin was $20 \mathrm{~g} / 100 \mathrm{~mL}$ for initial concentration of $600 \mathrm{mg} / \mathrm{L}$ with time equal to $30 \mathrm{~min}$ that achieved removal efficiency of $86 \%$. Also, the results proved that the waterworks sludge, ion-exchange resin and $\mathrm{CAC}$ are suitable for the remediation of synthetic leachate contained a different concentrations of $\mathrm{Cd}(\mathrm{II}), \mathrm{NH} 3-\mathrm{N}$ and $\mathrm{COD}$ respectively. The total removal efficiency was equal to $95 \%, 84 \%$ and $35 \%$ for $\mathrm{Cd}(\mathrm{II}), \mathrm{NH} 3-\mathrm{N}$ and $\mathrm{COD}$ respectively with best operating conditions that obtained from single batch tests. Results proved that the sorption process for all contaminants were correlated well by Langmuir model. In addition, kinetic data were correlated reasonably by the pseudo-second order with R2 and SSE greater than that of the pseudo-first order.

\section{Refrences}

[1] Amarasinghe, B.; Williams, A., (2007) "Tea waste as a low cost adsorbent for the removal of $\mathrm{Cu}$ and $\mathrm{Pb}$ from wastewater." Chemical Engineering Journal. https://doi.org/10.1016/j.cej.2007.01.016.
[2] Aziz, H. A.; Adlan, M. N.; Shahrir, M.; Zahari, M.; Alias, S., (2004) "Removal of ammoniacal nitrogen ( $\mathrm{NH}_{3}-\mathrm{N}$ ) from municipal solid waste leachate by using activated carbon and limestone." , 371-375. https://doi.org/10.1177/0734242X04047661.

[3] Bashir, M. J. K.; Aziz, H. A.; Amr, S. S. A.; Sethupathi, S.; Ng, C. A.; Lim, J. W., (2015) "The competency of various applied strategies in treating tropical municipal landfill leachate." Desalination and Water Treatment, 54(9), 2382-2395. https://doi.org/10.1080/19443994.2014.901189.

[4] Bashir, M. J. K.; Aziz, H. A.; Yusoff, M. S.; Huqe, A. A. M.; Mohajeri, S., (2010) "Effects of ion exchange resins in different mobile ion forms on semi-aerobic landfill leachate treatment." , 641-650. https://doi.org/10.2166/wst.2010.867

[5] Boaventura, R. A. R.; Duarte, A. A. S.; Almeida, M. F., (2000) "Aluminum recovery from water treatment sludges." In Proceedings of the IV International Conference on Water Supply and Water Quality (pp. 1-4). Retrieved from http://repositorium.sdum.uminho.pt/bitstream/1822/ 5906/1/ASDuarte_4\%25C2\%25BAWSWQ\%2520C rac\%25C3\%25B3via_2000.

[6] Brown, A. M., (2001) "A step-by-step guide to nonlinear regression analysis of experimental data using a Microsoft Excel spreadsheet." Computer Methods and Programs in Biomedicine, 65(3), 191-200.

[7] Bugbee, G. J.; Frink, C. R., (1985) "Alum Sludge as a Soil Amendment : Effects on Soil Properties and Plant Growth." Bulletin, (November), 1-7. https://doi.org/ISSN 0097-0905.

[8] Champagne, P.; Li, C., (2009) "Use of Sphagnum peat moss and crushed mollusk shells in fi xed-bed columns for the treatment of synthetic landfi 11 leachate." 339-347. https://doi.org/10.1007/s10163-009-0262-4.

[9] Dassanayake, K. B.; Jayasinghe, G. Y.; Surapaneni, A.; Hetherington, C., (2014) "A review on alum sludge reuse with special reference to agricultural applications and future challenges." Waste Management, 38(1), 321-335. https://doi.org/10.1016/j.wasman.2014.11.025.

[10] Ding, Y.; Sartaj, M., (2016) "Optimization of ammonia removal by ion-exchange resin using response surface methodology." International Journal of Environmental Science and Technology, 13(4), 985-994. https://doi.org/10.1007/s13762-016-0939$\mathrm{x}$.

[11] El-Sayed, G. O.; Dessouki, H. A.; Ibrahim, S. S., (2010) "Biosorption of Ni (II) and Cd (II) ions from 
aqueous solutions onto rice straw." Chemical Sciences Journal.

[12] Foo, K. Y.; Hameed, B. H., (2010) "Insights into the modeling of adsorption isotherm systems." Chemical Engineering Journal, 156(1), 2-10.

[13] Gheju, M.; Miulescu, A., (2007) "Sorption Equilibrium of Hexavalent Chromium on Granular Activated Carbon." Chem. Bull. Politechnica Univ. (Timişoara), 52, 1-2, 41-46.

[14] Guan, X.; Chen, G.; Shang, C., (2005) "Re-use of water treatment works sludge to enhance particulate pollutant removal from sewage." , 39, 3433-3440. https://doi.org/10.1016/j.watres.2004.07.033.

[15] Halim, A. A.; Abidin, N. N. Z.; Awang, N.; Ithnin, A.; Othman, M. S.; Wahab, M. I., (2011) "Ammonia and COD removal from synthetic leachate using rice husk composite adsorbent." Journal of Urban and Environmental Engineering, 5(1), 24-31. https://doi.org/10.4090/juee.2011.v5n1.024031.

[16] Ho, Y.-S.; McKay, G., (1999) "Pseudo-second order model for sorption processes." Process Biochemistry, 34(5), 451-465.

[17] Ho, Y. S.; Porter, J. F.; McKay, G., (2002) "Equilibrium isotherm studies for the sorption of divalent metal ions onto peat: copper, nickel and lead single component systems." Water, Air, and Soil Pollution, 141(1-4), 1-33.

[18] Hovsepyan, A.; Bonzongo, J. C. J., (2009) "Aluminum drinking water treatment residuals (AlWTRs) as sorbent for mercury: Implications for soil remediation." Journal of Hazardous Materials, 164(1), 73-80. https://doi.org/10.1016/j.jhazmat.2008.07.121.

[19] Ippolito, J. A.; Scheckel, K. G.; Barbarick, K. A., (2009) "Selenium adsorption to aluminum-based water treatment residuals." Journal of Colloid and Interface Science. https://doi.org/10.1016/j.jcis.2009.06.023.

[20] Jun, D.; Yongsheng, Z.; Weihong, Z.; Mei, H., (2009) "Laboratory study on sequenced permeable reactive barrier remediation for landfill leachatecontaminated groundwater." Journal of Hazardous Materials, 161(1), 224-230. https://doi.org/10.1016/j.jhazmat.2008.03.086

[21] Liu, R.; Zhao, Y.; Sibille, C.; Ren, B., (2016) "Evaluation of natural organic matter release from alum sludge reuse in wastewater treatment and its role in $\mathrm{P}$ adsorption Utilization areas Industrial use Risk concerns Land use." Chemical Engineering Journal, 302, 120-127. https://doi.org/10.1016/j.cej.2016.05.019
[22] Makris, K. C.; Sarkar, D.; Datta, R., (2006) "Aluminum-based drinking-water treatment residuals : A novel sorbent for perchlorate removal." , 140. https://doi.org/10.1016/j.envpol.2005.08.075

[23] Mathews, A. P.; Zayas, I., (1989) "Particle size and shape effects on adsorption rate parameters." Journal of Environmental Engineering, 115(1), 41-55.

[24] Mohammed, A.; Al-tahmazi, T.; Babatunde, A. O., (2016) "Attenuation of metal contamination in landfill leachate by dewatered waterworks sludges." Ecological Engineering, 94, 656-667. https://doi.org/10.1016/j.ecoleng.2016.06.123

[25] Mohammed, A.; Al-Tahmazi, T.; Babatunde, A. O., (2016) "Attenuation of metal contamination in landfill leachate by dewatered waterworks sludges." Ecological Engineering, 94, 656-667. https://doi.org/10.1016/j.ecoleng.2016.06.123

[26] Mohan, D.; Pittman, C. U., (2006) "Activated carbons and low cost adsorbents for remediation of tri- and hexavalent chromium from water." , 137, $762-811$.

https://doi.org/10.1016/j.jhazmat.2006.06.060

[27] Park, S.-J.; Kim, B.-J., (2005) "Ammonia removal of activated carbon fibers produced by oxyfluorination." Journal of Colloid and Interface Science. https://doi.org/10.1016/j.jcis.2005.05.012

[28] Puranik, P. R.; Modak, J. M.; Paknikar, K. M., (1999) "A comparative study of the mass transfer kinetics of metal biosorption by microbial biomass." Hydrometallurgy, 52(2), 189-197.

[29] Renou, S.; Givaudan, J. G.; Poulain, S.; Dirassouyan, F.; Moulin, P., (2008) "Landfill leachate treatment: Review and opportunity." , 150, 468-493. https://doi.org/10.1016/j.jhazmat.2007.09.077

[30] Salem, Z.; Hamouri, K.; Djemaa, R.; Allia, K., (2008) "Evaluation of landfill leachate pollution and treatment." Desalination, 220(1-3), 108-114. https://doi.org/10.1016/j.desal.2007.01.026

[31] Tahir, S. S.; Naseem, R., (2007) "Removal of Cr ( III ) from tannery wastewater by adsorption onto bentonite clay." , 53, 312-321. https://doi.org/10.1016/j.seppur.2006.08.008

[32] Wai, Y.; Ghyselbrecht, K.; Santos, R. M.; Martens, J. A.; Swennen, R.; Cappuyns, V.; Meesschaert, B., (2012) "Adsorption of multi-heavy metals onto water treatment residuals: Sorption capacities and applications." Chemical Engineering Journal, 200 202 , $405-415$. https://doi.org/10.1016/j.cej.2012.06.070

[33] Williams, P. T., (2005)Waste Treatment and Disposal: Second EditionWaste Treatment and 
Disposal: $\quad$ Second

https://doi.org/10.1002/0470012668

[34] Yuh-Shan, H., (2004) "Citation review of Lagergren kinetic rate equation on adsorption reactions." Scientometrics, 59(1), 171-177.

[35] Zagorodni, A. A., (2006)Ion exchange materials: properties and applications. Elsevier.

[36] Zhao, Y. Q.; Babatunde, A. O.; Hu, Y. S.; Kumar, J. L. G.; Zhao, X. H., (2011) "Pilot field-scale demonstration of a novel alum sludge-based constructed wetland system for enhanced wastewater treatment." Process Biochemistry, 46(1), 278-283. https://doi.org/10.1016/j.procbio.2010.08.023

[37] Zheng, H.; Liu, D.; Zheng, Y.; Liang, S.; Liu, Z., (2009) "Sorption isotherm and kinetic modeling of aniline on Cr-bentonite." Journal of Hazardous Materials, 167(1-3), 141-147.

[38] Zhou, Y.; Haynes, R. J., (2011) "Removal of Pb ( II ), Cr ( III ) and Cr ( VI ) from Aqueous Solutions Using Alum-Derived Water Treatment Sludge." , 631-643. https://doi.org/10.1007/s11270-010-0505$\mathrm{y}$.

معالجة راشح مو اقع الطمر بأستخدام الحمأة الناتجة من محطات الثرب ومو اد تقليدية أخرى

إسراء محمود علي 1، أرياد عبد الحمزة فيصل 2

is87raa@yahoo.com قسم العندسة البيئية، جامعة بغداد، بغداد، العراق،

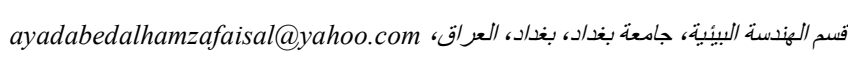

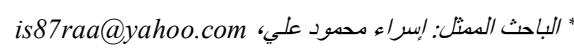
شر في: 31 آب 2019

الخلاصة ـ التحقق من إمكانية إستخدام الحمأة الناتجة من محطات معالجة مياه الثرب في معالجة المياه المشابهة بخصائصها للمياه الر اشحة

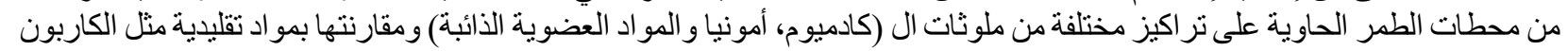

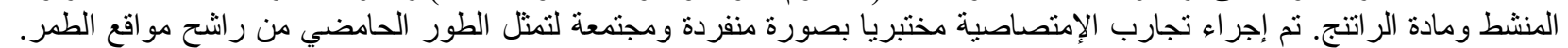

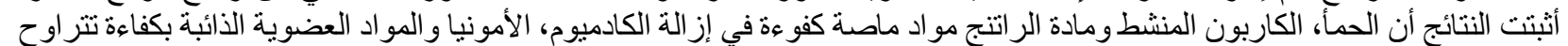

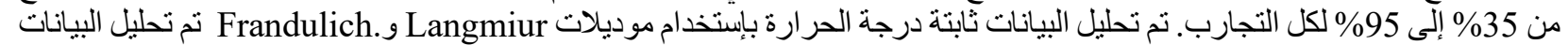

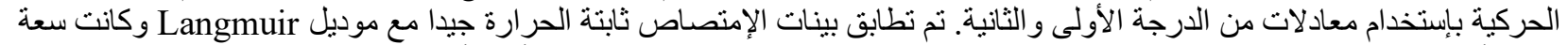

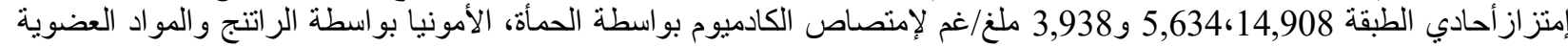
الذائبة بواسطة الكاربون المنشط على التوانة التي. الكلمات الرئيسية ـ الر اشح، حمأ محطات معالجة مياه الثرب، الموديلات الحركية، الموديلات ثابتة درجة الحرارة، مو اد تقليدية. 